\section{Marketing Communication of Selected Conservative and Liberal Parties in Slovak Region Before Elections}

\author{
Denisa Jánošová \\ University of Ss. Cyril and Methodius in Trnava, Slovakia \\ https://orcid.org/0000-0003-2826-7463
}

Renáta Bundzíková

University of Ss. Cyril and Methodius in Trnava, Slovakia

https://orcid.org/0000-0001-6578-9792
Political Preferences

2020, vol. 26: 27-40

journals.us.edu.pl/index.php/PP

Submitted: 20/04/2020

Accepted: 14/06/2020

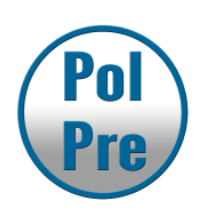

\begin{abstract}
:
Through a democratically set system of state functioning, political parties are given space for their establishment and subsequent functioning. Nowadays, registering new parties is not an issue in Slovakia, but another issue arises - most political parties cannot attract voters, and as a result they lose general sympathy and also necessary votes in elections. For a political party to become known to its voters, it needs to address and subsequently implement techniques of political marketing. Reaching and gaining voters is essential for a political party to continue to exist. By using marketing communication in its election campaign, a political party can succeed more than the one that has not used them. Therefore to adequately address its voters, a political party has to know their social, cultural, economic as well as religious background. The political party must also pay attention to the creation of an election program that appeals to voters. However, a political party should choose such proper communication channels through which it will be able to attract its supporters. The presented paper deals with the issue of using / not using marketing communication before the parliamentary elections in 2020 in selected Slovak conservatively and liberally oriented political parties in the Trenčín region. The authors present their findings on the basis of the analysis of marketing communication tools, as well as formuate research questions that helped them meet the research goal, in particular, whether selected political parties used/did not use specific marketing communication tools in their election campaign in 2020.
\end{abstract}

Keywords: marketing communication, marketing communication tools, political marketing, political parties, voters, Trenčín region

\title{
Introduction
}

During the election campaign, we can observe the significance of political influence on the supporters of individual parties. Political propaganda is generally a well-known term for 
influencing people in the election campaign. Nowadays with the gradual development of technology, we also notice a change in the goals of political propaganda towards voters. The means to achieve the most active election campaign are continually changing and also depend on the use of current marketing trends in politics (Hradiská 2010). However, the ideal model for a successful election campaign is not yet known. It is, therefore, up to the political party itself to choose how to reach the voters. Due to the uniqueness of the election campaign, a political party can either gain voters or not.

The pre-election campaign is influenced by various factors, such as country's history, political literacy of voters, current political situation in the country, size and diversity of the political market, political party competition, background of candidates and the image of the political party itself. In Slovakia, the cases of candidates of political parties and the financing of their campaigns are mainly addressed in the pre-election period (Chytílek et al. 2012; Štědron̆ 2013). Political parties try to compete with each other. Opponents are often discredited in front of the public, especially in the context of preventing candidates from political parties or questioning the financing of the election campaign, especially the transparency of how the financial resources were used. We can conclude that voters usually do not react to the quality of proposed programs of political parties. However, they want to know the background of candidates - their conflicts, extremist attitudes or conflicting views with other political parties.

Despite the various factors that create a burden on a political party, its members need to focus on the importance of using up-to-date information technology towards voters. Today, the Internet and social media are some of the most important means of sharing and transmitting the information. People like to be informed and information is spread very quickly through the mentioned information technologies. The change in the rules used so far in political marketing is caused by on-line space. For those who know how to use on-line and off-line space for the benefit of their political campaign, the media are becoming a handy tool for achieving their goals.

\section{Political marketing}

Political marketing is an integral part of the communication of political parties, which concerns not only the pre-election period but also their entire existence. Political marketing started to gain its importance in Slovakia with the establishment of the Slovak Republic in 1993. The reign of democracy in the country resulted in the general public gradually appreciating the speeches of 
politicians, their work with selected groups of sympathizers, etc. (Smolková et al. 2016; Jabłoński \& Kopeček 2006). Also crucial were the means and methods of political marketing used by politicians towards their voters. Political behavior had a significant influence on the voters of a particular political party, which was ultimately reflected in the election results. Political parties using political marketing during their campaign were able to rapidly increase the percentage of voters and continue to sustain them.

Similarly to the market mechanism, we encounter the supply and demand also in political marketing. On the supply side, there is a political party with its ideas and program. On the demand side, some voters expect change to come with the elections. Thus, in a democratic society, the product represents the program of a political party, and voters are customers who are interested in it if they sympathize with a particular political party (Ormrod et al. 2013). During election campaigns, we observe an electoral product that each political party has designed differently. The electoral product is characterized by its integrity, which influences the voter. It is not only a program but also the presentation of political parties to the public. The connection between politics and marketing can be found in the promotion of the election product itself (Křeček 2007). The election product is distributed mainly in the pre-election period, using various on-line or off-line media chosen by the political party.

Political marketing is not just a combination of marketing and political science. Political marketing involves several scientific disciplines, such as psychology, sociology, law and other social and human sciences. Political marketing has found its use mainly in election campaigns. Also, political marketing is related to media events, the distribution of PR gifts on the occasion of meetings of politicians with their voters, and the predefined display of the logo in a visible place of the gift (Smolka 2015). This includes other communication procedures that the political party has used so far in the pre-election period. The marketing activities that are related and used to reach the voters are diverse and it is up to the political party of their choice. However, the goal of marketing activities should be primarily to address and open the communication with the voter, which leads to the electoral vote and thus supports the success of the political party in the election. Political party candidates usually hold debates in various media discussing their electoral programs, visions and strategies in order to reach the broadest possible range of the population. 
For the public political marketing has become a part of media influence. Today, we can certainly name the tools that politicians use to influence their future voters. It is all about influencing not only in the short-term but also the long-term period (Elder 2016). With the gradual development of the media, but also of the means intended for communication, it was necessary to look for such communication tools that would be able to deliver the message, visions and strategies of the political party to the broadest possible public. Because only by using the broadest possible range of means of communication, is it possible for a political party to reach as many of its voters as possible (Lees-Marshment 2014). Today, political parties are aware of the importance of marketing activities used in politics. Therefore, they are continually looking for ways to link and connect marketing to their political agenda. Also, they put more and more trust in marketers of political or election campaigns, who can help them achieve their goal. The target of political marketing is not just the implementation of campaigns (Štensová \& Štarchoň 2009; Kubáček 2012). It is about monitoring the marketing environment, its analysis and how to design marketing strategies. Political marketing is a collection of theory, marketing techniques, methods and tools, and therefore there is an opportunity to run a political campaign at a professional level. Each political campaign is specific and requires the use of other methods and tools during its course compared to the previous one. The current political market requires the use of such techniques which will enable a political party to share its ideology and preferred values of its leaders. This may further follow the creation of an offer, which is requested by the supporters of a political party. However, we often witness an ineffective election campaign, which is wellfunded but not primarily marketing-oriented and thought through.

The success of political marketing depends primarily on research, which includes analyzing the environment, current views and preferences of voters. Also, it is necessary to analyze the strengths and weaknesses of the candidates of a particular political party (Ivantysyn 2009; Slovák 2016). This identification can support the political party in its further development and steps to achieve the set goal. Changing voter preferences can also bring about a change in the strategy of a political party. It is, therefore, important to use a way that meets the requirements of voters. It should be crucial for a political party to set goals and gradually achieve them. Also, the importance of chosen communication channels and verification of the correctness of the set goals through the implementation of public opinion polls is crucial. 


\section{Communication mix of the election campaign}

Currently, several tools of marketing communication in the world of politics are used, which influence the decision-making of voters in the pre-election period. The most commonly used include advertising, public relations, personal selling and direct marketing. Perhaps every political party uses advertising on television or radio. With the development of communication media, social media and the Internet have become the leaders. We can increasingly observe the use of social networks to promote political ideologies. Social networks are preferred by political parties closer to young people and families when communicating their election program (Šaradín 2007). Political advertising in the off-line environment can be perceived by voters in, for example, local or regional newspapers. Most candidates of political parties prefer the distribution of leaflets and catalogues describing their profile and election program. The distribution of leaflets can ultimately be more costly than, for example, advertising on social networks, which can become viral. Likewise, billboards are very popular among politicians in Slovakia, but also financially demanding. In political marketing, the term personal selling means the personal communication of information by candidates towards voters (Williams 2017). It is a financially and time-consuming form of promotion, but it proves to be the most effective. During the election period,the candidates of political parties must comment publicly on the scandals or unclear circumstances. Positive public relations contribute to the image of a political party.

An election campaign for the National Council of the Slovak Republic took place in Slovakia in February 2020. Political parties could launch their election campaign on November 5, 2019. However, political advertising began to be broadcast on radio and television only on February 8, 2020. Since this date, it was also possible to start with the broadcasting of discussion programs and the promotion of political parties' election programs. According to the law, the election campaign must end 48 hours before the election, because an information moratorium is then in force (Smolková et al. 2016). The statement of the Broadcasting and Retransmission Council also states that the results of election polls may not be published 14 days before the elections. This prohibition applies until the end of voting in the elections. The Broadcasting and Retransmission Council does not take into account the amendment to the law, which covers the extension of the moratorium on the publication of the results of public opinion polls from 14 to 50 days. 


\section{Methodology}

In our analysis, we focus on the use/non-use of marketing communication tools of selected Slovak conservative and liberal parties in the Trenčín region. In this case, conservative and liberal parties are understood as Slovak political parties, whose ideology is also focused on conservatism or liberalism. We focus on the Trenčín region due to the use of knowledge gained from the analysis for possible future use in our dissertation thesis. For the analysis, we randomly chose three political parties with an ideology focused also on conservatism and three political parties focused also on liberalism. The condition was that they were Slovak political parties and that they ran for the parliamentary elections in 2020. The analysis took place in January 2020. We analyzed the use/non-use of marketing communication tools in the off-line and on-line environment. For analysis in the off-line environment, we selected the following tools: billboards, leaflets, news, promotion and PR meetings. We have selected the following tools for analysis of the on-line environment: social media, promotion and live stream. We consider the presented selected off-line and on-line tools to be essential in the use of political marketing and, thus, for the overall communication of the political party towards future voters. We analyzed all those as mentioned above off-line and on-line tools through which selected political parties communicated/did not communicate in the pre-election period and we processed the results in Table 1 and Table 2. The results also include four research questions, which we identified before the analysis to find out the use/non-use of marketing communication tools of political parties. Research questions are an essential part of our analysis and their specifics were chosen based on studied election surveys and long-term monitoring of the issues addressed in order to obtain relevant data. The answers to the research questions were provided by our analysis.

\section{Results}

\section{Marketing communication of political parties with the conservative ideology}

The term conservatism has its origins in the Latin conservare, which means to preserve. The concept of conservatism could have been presented to people as early as the end of the 18th century on the occasion of a response to the changes brought by the French Revolution. Conservatism is based on the rejection of change, adheres to old practices, has moderate behavior and a conventional lifestyle (Fiala \& Mikš 2019). The political ideology of conservatism is the belief that radical change cannot be made. Also, this direction taken by political parties considers 
the current situation in the country as sufficient enough. This implies that conservatives hold traditional historical values (Coulter 2013; Obšitník 2007). Likewise, proponents of this direction prioritize overarching interests over the interests of individuals. Today, Republican parties and Christian Democratic parties are formed by conservatives. A typical example is the British Conservative Party.

In Slovakia, conservative political parties have been shaping since 1989. In general, the Slovak population is considered to be a conservative voter. This fact may be due to strong religious influence, majority belief in Christian values, and relatively stable national awareness and proudness (Pipes 2018; Ziblatt 2017).

SMER-SD. The Slovak Social Democratic political party - SMER-SD was founded in 1999 by the Ministry of the Interior of the Slovak Republic. Its chairman has been Róbert Fico from the beginning. Initially, the party has profiled itself as a third option since its inception. Only gradually it started to focus on the left orientation and social democracy (an abbreviation of SD in the name). This became the dominant left-wing political party in Slovakia. The political party appears pro-European; however, within social issues, it is quite conservative (SMER-SD 2020). Representatives of a political party have a negative attitude towards Muslims and migrants from third countries. They also face daily criticism from the liberal public and questions about the decriminalization of marijuana, registered partnerships, and separation from church and state (SMER-SD 2020).

SNS - Slovenská národná strana (Slovak National Party). The political party - SNS - is one of the oldest in Slovakia. It was founded in 1871, but its modern form was created in 1990 by registration with the Ministry of the Interior of the Slovak Republic. Its chairman is Andrej Danko. It is a political party that is nationally oriented, upholds the ideology of conservatism and claims to adhere to the European-Christian value system (SNS 2020). It has three program pillars: national, Christian and social. SNS promotes the absolute program priority of the sovereign Slovak Republic. It also prioritizes the equality of all the country's inhabitants, regardless of nationality or religion (SNS 2020). The leader Andrej Danko tries to spread the mission of the party and leads its members to peace, nation, honesty, humanity and morality values. 
LSNS - Ludová strana Naše Slovensko. LSNS started its political activity in 2009 and it focuses mainly on three principles, which are similar to the SNS party: nation, socialism and Christianity. The chairman of the political party is Marián Kotleba. The party states that it is the only one that can offer its voters a change in the form of real opposition to a state that is corrupted, in their opinion. Also, the party promotes conservative views held in the past by prominent Slovak historical figures such as Ludovít Štúr, Andrej Hlinka and Jozef Tiso (LSNS 2020). It is essential for a political party that Slovakia is neutral, politically independent and economically self-sufficient, safe for its inhabitants, socially just, economically prosperous, Christianly and morally preserved, educated and cultural. LSNS party is severely criticized by the liberals for the approach that the Holocaust was just fiction.

Table 1. Marketing communication tools - political parties with a conservative orientation

\begin{tabular}{|c|c|c|c|c|c|c|c|c|}
\hline \multirow[b]{2}{*}{$\begin{array}{c}\text { Political } \\
\text { parties }\end{array}$} & \multicolumn{5}{|c|}{ off-line marketing tools } & \multicolumn{3}{|c|}{ on-line marketing tools } \\
\hline & billboards & leaflets & news & promotion & $\begin{array}{c}\text { PR } \\
\text { meetings }\end{array}$ & $\begin{array}{l}\text { social } \\
\text { media }\end{array}$ & promotion & $\begin{array}{c}\text { live } \\
\text { stream }\end{array}$ \\
\hline $\begin{array}{c}\text { SMER- } \\
\text { SD }\end{array}$ & $\checkmark$ & $x$ & $\boldsymbol{\nu}$ & $\checkmark$ & $\boldsymbol{\nu}$ & $\checkmark$ & $\boldsymbol{\nu}$ & $\checkmark$ \\
\hline SNS & $\checkmark$ & $x$ & $\checkmark$ & $\checkmark$ & $x$ & $\checkmark$ & $\checkmark$ & $x$ \\
\hline LSNS & $\checkmark$ & $\boldsymbol{\nu}$ & $\checkmark$ & $\checkmark$ & $\checkmark$ & $\checkmark$ & $\checkmark$ & $x$ \\
\hline
\end{tabular}

Source: own processing.

Before carrying out the analysis, we identified two research questions regarding the use/non-use of marketing communication tools, which relate to the mentioned conservatively oriented political parties. Below we present the questions as well as the answers.

Research question 1: What marketing communication tools, chosen by us, have been used by the political parties of SMER-SD, SNS and L'SNS for their promotion in off-line and on-line environments?

Research question 2: What marketing communication tools, chosen again by us, have not been used by the political parties of SMER-SD, SNS and LSNS for their promotion in off-line and online environments?

Political conservative parties used several marketing communication tools in the parliamentary elections to the Trenčín region. The off-line environment was dominated by billboards, advertisements in local and regional newspapers as well as PR meetings in the cities 
of the Trenčín region. Most political parties in Slovakia choose marketing communication through billboards. In previous election campaigns, familiar faces of party candidates appeared on billboards. nowadays this is not a priority anymore. Political parties also decide, for example, on links associated with their election program placed on billboards. In the pre-election period, political parties also sought direct contact with their voter and therefore visited several cities in the Trenčín region to promote themselves. At the meetings, the party's election program and its successes were discussedthose were not only formal meetings but also, for example, events connected with the agro-industry, etc. influencing voters also took place in the on-line environment using social networks. Each mentioned party has its Facebook-based fanpage with the communication via short posts or videos to its followers. Likewise, the usual social media venue is the Youtube channel. Each analysed political party has its channel.. Communication with voters takes place through videos in which individual representatives explain the party's election programs or react to the issues that arise on spot. Candidates need to comment on the cases that have arisen, as they may affect their future involvement in politics. The SMER-SD political party had a problem with the copy of an ad. The political party has been accused of imitating the Israeli version of an advertisement by Aaron Shaviv's agency.

\section{Marketing communication of political parties with the liberal ideology}

In general, we can characterize liberalism by the word tolerance, which is open to other views and ideologies. Liberalism dates back to the Enlightenment period when a free view of the world was created. The basis for liberalism is the individual whose freedom is the most important (Close \& Van Haute 2019). Liberalism can also be expressed as a system of economic, political and social views that strive to achieve the rights of individuals, freedom and often the idea of general social progress (Obšitník 2007). Formerly, tolerance was also promoted in liberalism in connection with religion and morality, the right to private property, and the free market (Selfa 2012; Mill 2005). Liberalism was negatively predisposed to issues of state intervention. However, in the later directions of liberalism, we do not observe these views anymore. It can also be questionable for liberalism, for example, that some liberals are intolerant of other political attitudes. Also, Christian liberals do not promote religious tolerance but Christianity, and in leftwing liberalism, we are more concerned with the promotion of some left-wing principles. The opposite of liberalism is totalitarianism. The liberal direction in Slovakia has been set by political 
parties since 1989. Most of them are political parties that have not historically influenced the country's history. Liberal parties are not represented in large numbers in the developed countries of the world. Instead, it is a matter of balancing the parliament with liberal parties (Hobhouse 2002). However, the influence of liberal parties in Europe is relatively stable.

SaS - Sloboda a Solidarita (Freedom and Solidarity). SaS - political party describes itself as right-liberal (SaS 2020). Its chairman is Richard Sulík. SaS was founded in 2009. The vision of a political party is to make it worthwhile for the individuals to work, do business and live in Slovakia. They prioritize the well-being of the individual because the satisfaction of individuals leads to the satisfaction of the whole society ( $\mathrm{SaS}$ 2020). The political party is slightly sceptic about Europe. Following the 2019 elections, it is represented by two members in the European Conservatives and Reformists fraction.

SPOLU - občianska demokracia (TOGETHER - civic democracy). The political party holds pro-European views and was registered in 2018; it focuses on economic liberalism (SPOLU 2020). Its chairman is Miroslav Beblavý. So far, the party has managed to participate in the municipal elections in 2018. Its candidates succeeded in winning approximately 350 deputies and 19 mayoral posts. The political party continues to run parliamentary elections in coalition with the Progresívne Slovensko party. in its election program SPOLU - občianska demokracia focuses on changes mainly in the area of a strong economy, security and justice in the country as well as on the quality of life in the country (SPOLU 2020).

Dobrá vol'ba (Good choice). Dobrá vol'ba is a political party focused on the ideology of liberalism, founded by its chairman Tomáš Drucker in 2019 (Dobrá vol'ba 2020). At the Ministry of the Interior of the Slovak Republic, party members submitted 30,000 signatures of citizens who were in favor of establishing this party. Dobrá vol'ba is one of the youngest political parties in Slovakia. Candidates claim to have came up with a policy that is based on values and human and social values are among the most critical (Dobrá vol'ba 2020). They claim the importance of belonging, respect, cooperation, honesty and mutual respect. Their vision is to fight for valid values and not to fight against individual parties or their candidates. 
Table 2. Marketing communication tools - political parties with a liberal orientation

\begin{tabular}{|c|c|c|c|c|c|c|c|c|}
\hline \multirow[b]{2}{*}{$\begin{array}{l}\text { Political } \\
\text { parties }\end{array}$} & \multicolumn{5}{|c|}{ off-line marketing tools } & \multicolumn{3}{|c|}{ on-line marketing tools } \\
\hline & billboards & leaflets & news & promotion & $\begin{array}{c}\text { PR } \\
\text { meetings }\end{array}$ & $\begin{array}{l}\text { social } \\
\text { media }\end{array}$ & promotion & $\begin{array}{c}\text { live } \\
\text { stream }\end{array}$ \\
\hline SaS & $\checkmark$ & $\boldsymbol{v}$ & $\boldsymbol{v}$ & $\checkmark$ & $\checkmark$ & $\bar{v}$ & $\boldsymbol{V}$ & $x$ \\
\hline SPOLU & $\boldsymbol{v}$ & $x$ & $v$ & $\checkmark$ & $v$ & $\checkmark$ & $\boldsymbol{v}$ & $x$ \\
\hline $\begin{array}{l}\text { Dobrá } \\
\text { vol'ba }\end{array}$ & $v$ & $x$ & $\boldsymbol{v}$ & $\checkmark$ & 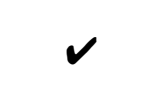 & $\boldsymbol{v}$ & $\boldsymbol{v}$ & $x$ \\
\hline
\end{tabular}

Source: own processing.

Also, before carrying out the analysis, we identified two research questions regarding the use/non-use of marketing communication tools related to the mentioned liberal-oriented political parties. Below we state the questions as well as the answers.

Research question 1: What marketing communication tools, chosen by us, have been used by the political parties of SaS, SPOLU and Dobrá vol'ba for their promotion in off-line and on-line environments?

Research question 2: What marketing communication tools, chosen again by us, have not been used by the political parties of SaS, SPOLU and Dobrá vol'ba for their promotion in off-line and on-line environments?

Marketing communication of liberally oriented political parties took place in both off-line and on-line environments. Each party used billboards for the election campaign, where it communicated its positions or excerpts from the election program. Voters in the Trenčín region were able to read the election campaign of political parties in local and regional newspapers. They provided the parties with the space to advertise that was accepted by the parties. Perhaps the most striving political party in the context of PR meetings with its voters was SPOLU. Its goal was to visit all municipalities in Slovakia, which is financially straining but also time-consuming. Pre-election discussions of individual party candidates were broadcasted on television, providing the chance to influence a wide range of voters. Each political party used a Facebook page for its promotion, where it most often communicated the election program or tried to raise awareness about the values of the family, belonging, etc. Likewise, political parties tried to share commercials on social networks, urging voters to vote in elections in their favor.

We consider the research questions we set at the beginning of the research to be answered. Also, our goal, concerning the identification of the use/non-use of marketing communication tools of selected political parties in the Trenčín region, has been met. This paper can serve as an 
inspiration for further research into the use of marketing communication tools of other political parties, possibly in another region, with subsequent comparison of other findings.

\section{Conclusion}

Every election campaign of a political party, whether partly conservative or liberal-oriented, involves the use of marketing communication tools. More and more political parties prefer the services provided by advertising agencies, taking care of the processing of their ideas for the election campaign. However, it is still questionable whether the overall feeling of the campaign will also have a professional effect on potential voters or supporters of the party. The tools of marketing communication are relatively the same in election campaigns of conservative and liberal parties. It is up to the political party which tools it wants to use and what trends the advertising agency will suggest. When choosing the tools of marketing communication, it is necessary to consider the target group to which we would like to communicate the message and, thus, the election program or vision of the political party. Nowadays, political parties use off-line as well as on-line marketing communication tools. Communication is a crucial aspect of the election campaign.Without proper communication, voters would not know about the political party. Although relatively similar marketing communication tools are used in the election campaign, we observe a difference in the communication style of conservative and liberal parties. Conservative parties communicate the interests of society as well as Christian and national values. For liberal parties, communication is focused on the rights and freedoms of individuals, because only then can society as a whole be satisfied. A wide range of marketing communication tools can provide a political party with more influence over voters. However, sometimes more is less, because, during the election period, the influence and pressure on the voter are too strong. The ideal case is when a political party takes care of its potential voters on an ongoing basis, even outside the election period. The members of the party can thus gradually build trust between them and the voters, who, in turn, vote for them in the elections. Perhaps the biggest disappointment to voters are the promises of the political parties they voted for, that are not going to be fulfilled. 


\section{Funding:}

The paper is an output of the research project supported by the Grant Agency of the Ministry of Education of the Slovak Republic and the Slovak Academy of Sciences (VEGA) No. 1/0078/18 titled Aspects of Marketing Communication in the Management Processes of Circular Economy.

\section{References:}

Chytílek, R., Eibl, O., \& Matušková, A. (2012). Teorie a metody politického marketingu [Theory and methods of political marketing]. Brno: Centrum pro studium demokrace a kultury.

Close, C., \& Van Haute, E. (2019). Liberal parties in Europe. New York: Routledge.

Coulter, A. (2013). Mugged: Racial Demagoguery from the Seventies to Obama. New York: Sentinel.

Dobrá vol'ba. (2020). About political party. https://dobravolba2020.sk/\#program (20/03/2020).

Elder, E. (2016). Marketing leadership in government: Communicating Responsiveness, Leadership and Credibility. Palgrave Studies in Political Marketing and Management.

Fiala, P., \& Mikš, F. (2019). Konzervatismus dnes: Politika, společnost a zdravý rozum v době nerozumu [Conservatism Today: Politics, Society, and Common Sense in a Time of Misunderstanding]. Brno: B\&P Publishing.

Hobhouse, L. T. (2002). Liberalizmus. Bratislava: Kalligram.

Hradiská, E. (2010). Psychológia v marketingovej komunikácií [Psychology of marketing Communications]. Bratislava: Univerzita Komenského.

Ivantysyn, M. (2009). Main trends in Slovakia's political system. IWM Junior Visiting Fellows Conferences, 7, 2536.

Jabłoński, W., \& Kopeček, L. (2006). Politický marketing: úvod do teórie a praxe [Political Marketing: theory and practice]. Brno: B\&P Publishing.

Křeček, J. (2007). Politická komunikace [Political Communication]. Praha: Grada Publishing.

Kubáček, J. (2012). Slovník politického managementu a volebního marketing [Dictionary of political management and electoral marketing]. Praha: Grada Publishing.

Lees-Marshment, J. (2014). Political marketing: principles and applications. $2^{\text {nd }}$ ed. New York: Routledge.

LSNS (2020). About LSNS. https://volby.aktuality.sk/volby-2020/politicke-strany/kotlebovci-ludova-strana-naseslovensko/ (20/03/2020).

Mill, J. S. (2005). Logika liberalizmu. Bratislav: Kalligram.

Obšitník, L. (2007). Konzervativizmus versus liberalizmus [Conservatism versus liberalism]. https://www.postoj.sk/391/konzervativizmus-versus-liberalizmus (20/03/2020).

Ormrod, R. P., Henneberg, S. C., \& O'Shaughnessy, N. J. (2013). Political marketing: theory and concepts. LondonThousand Oaks: Sage.

Pipes, D. (2018). Conservatism's hidden history. The Philadelphia Inquirer. https://www.inquirer.com/philly/opinion/commentary/conservativisms-hidden-history-opinion-20180730.html $(20 / 03 / 2020)$.

Šaradín, P. (2007). Politické kampaně, volby a politický marketing [Political campaigns, elections and political marketing]. Olomouc: Periplum.

SaS (2020). Volebný program. https://www.sas.sk/detail/5496/nr-sr-2020/subory (20/03/2020).

Selfa, L. (2012). The democrats: A critical history. Chicago, IL: Haymarket Books. 


\section{Denisa Jánošová, Renáta Bundzíková}

Slovák, R. (2016). Stále prevláda klišé a amatérčina. Stratégie, 22(3), 14-15.

SMER-SD. (2020). About party's ideology. https://www.strana-smer.sk/o-nas/o-nas (20/03/2020).

Smolka, S. (2015). Vplyv politického marketingu na správanie voličov [The influence of political marketing on voter behavior]. In: Sborník př́spěvkú 8 . mezinárodní vědecké konference doktorandú a mladých vědeckých pracovníkú. Karviná: Slezská univerz ita v Opavě, Obchodně podnikatelská fakulta, 279-88.

Smolková, E., Smolka, S., \& Štarchoň, P. (2016). Political marketing - current approaches and trends in Slovakia. In: Conference Proceedings, Vol. 1., Book 2: Political Sciences, Law, Finance, Economics and Tourism. Hofburg: SGEM Vienna, 373-80.

SNS (2020). Profile of political party. https://www.sns.sk/o-nas/profil/ (20/03/2020).

SPOLU (2020). Volebný program. https://progresivnespolu.sk/bod-zlomu (20/03/2020).

Štědroň, B. (2013). Politika a politický marketing [Politics and political marketing]. Praha: C.H. Beck.

Štensová, A., \& Štarchoň, P. (2009). Selected aspects of political marketing in Slovakia. Central European Journal of Communication, 2(3), 319-27.

Williams, C. B. (2017). Introduction: Social Media, Political Marketing and the 2016 U.S. Election. Journal of Political Marketing, 16(3-4), 207-11.

Ziblatt, D. (2017). Conservative parties and the birth of democracy. Cambridge: Cambridge University Press. 